\title{
Development of an objective tool for the diagnosis of myxedema coma
}

\author{
Yien Vickie Chiong ${ }^{1}$, Elaine Bammerlin², and Cary N. Mariash ${ }^{3}$ \\ Department of Medicine, Indiana University School of Medicine and Methodist Research \\ Institute, Indianapolis, IN 46202
}

Running head: Myxedema coma diagnostic tool

${ }^{1}$ Parkview Endocrinology

Parkview Medical Office Building

1600 N. Grand Avenue, Suite 150

Pueblo, Colorado 81003

vickie.chiong@gmail.com

Tel: 719-595-7563

Fax: 719-595-7907

${ }^{2}$ Indiana University Health Methodist Hospital

1800 N. Capitol Avenue, Suite E504

Indianapolis, Indiana 46202

ebammerlin@iuhealth.org

Tel: 317-962-6461

Fax: 317-962-9369

${ }^{3}$ Medical Director, Methodist Research Institute

Indiana University Health Methodist Hospital

1812 N. Capitol Avenue

Indianapolis, Indiana 46202

cmariash@iuhealth.org

Tel: 317-962-6478

Fax: 317-962-5954

This study was presented at ENDO 2011: The $93^{\text {rd }}$ Annual Meeting \& Expo in Boston, Massachusetts on 6/6/2011.

Corresponding author: Cary N. Mariash, MD 


\begin{abstract}
Myxedema coma, a rare entity with a reported 25-65\% mortality had no objective criteria for making the diagnosis when we began our study. We developed an objective screening tool for myxedema coma to more easily identify patients and examine the best treatment method in future prospective studies to reduce the mortality of this entity. We conducted a retrospective chart review to find all patients aged $\geq 18$ years admitted with myxedema coma from 1/1/2005 through 6/13/2010 at Indiana University Health Methodist Hospital. Based both on our retrospective chart review and on literature-based accounts, we identified 6 criteria to diagnose myxedema coma. We identified 10 patients initially diagnosed with myxedema coma and established a control group consisting of 13 patients identified with altered mental status and elevated TSH levels. The six variables we created for the screening tool are heart rate, temperature, Glasgow coma scale, thyroid stimulating hormone, free T4, and precipitating factors. The screening tool has a sensitivity and specificity of about $80 \%$. We ran a logistic regression model using the 10 study patients and 13 controls with the 6 variables. No variables alone significantly contributed to the model. However, the overall model was highly significant ( $P=0.012$ ), providing strong support for a scoring system that uses these variables simultaneously. This screening tool enables physicians to rapidly diagnose myxedema coma to expedite treatment. A more refined diagnostic tool may be used in future clinical studies designed to determine the optimal treatment.
\end{abstract}




\section{INTRODUCTION}

Myxedema coma is a rare entity that often presents as a diagnostic challenge due to the rarity of the condition and its insidious onset [for reviews see (1-3)]. Unrecognized and untreated, the condition is often fatal, with reported mortality approximately $30-50 \%$. A key to the diagnosis of myxedema coma is the physician's in-depth knowledge of the illness, but the ER physician or hospitalist receives little guidance. Hampering early recognition of myxedema coma is the lack of set criteria for its diagnosis. There is no adequate standard definition of myxedema coma. Nor is there a true etiology. The clinical signs that have been associated with the disease are numerous, as is the list of abnormal laboratory results (4). Most articles in the medical literature agree that myxedema coma is suggested clinically by the presence of altered mental status, hypothermia, and identification of a precipitating factor such as cold exposure, sepsis, or drugs $(2,5,6)$. Biochemically, serum T4 and T3 concentrations are reduced with either elevation of thyroid stimulating hormone (TSH) in primary hypothyroidism or low or normal TSH in secondary hypothyroidism. However, it is important to emphasize that patients reported in the literature to have myxedema coma do not present with all the aforementioned features. Indeed, altered mental status without coma is commonly reported in patients with myxedema coma. A precipitating factor may be evident in less than $50 \%$ of cases (7). The non-specific presenting feature of myxedema coma is a complicating factor in making the correct diagnosis, and without the diagnosis, treatment cannot be optimized. It is widely acknowledged that the lethal nature of this disease demands early recognition and proper treatment, although proper treatment has not yet been established.

In an effort to improve treatment for these patients, we have focused first on defining the clinical entity. Our study was prompted by an unexpectedly high number of patients who were 
admitted to our institution with a diagnosis of myxedema coma in a 5-year period. We conducted a retrospective chart review and used these cases to develop an objective screening tool to help correctly classify such patients. Our ultimate goal is to reduce the mortality of patients with myxedema coma through early recognition and optimal treatment. Our preliminary results were presented at the 2011 Endocrine Society meeting (8), and we now present our full study. We propose that a future prospective multicenter study be conducted using an objective diagnostic tool to determine the optimal treatment for myxedema coma. 


\section{METHODS}

\section{SETTING AND STUDY DESIGN}

This was a retrospective chart review analyzing all patients aged 18 years and older admitted with a diagnosis of myxedema coma between January 1, 2005 and June 13, 2010 at IU Health Methodist Hospital. For control subjects, we reviewed charts of patients during that same time period who had both an elevated TSH and altered mental status but were not given a diagnosis of myxedema coma.

The data analyzed in this study were retrieved from the medical records department and consist of electronic records and paper charts. The access to and analyses of the database were approved by the Indiana University Institutional Review Board (IRB) and conforms to relevant ethical guidelines for human research.

All patients with an admitting diagnosis of myxedema coma recorded in their charts between January 1, 2005 and June 13, 2010 were identified. During this period of review, although a diagnosis of myxedema coma was recorded, a specific ICD-9-CM code for myxedema coma was not yet available. Instead, the diagnostic coding for these patients included Hypothyroidism (ICD-9-CM codes 243-244.9), Altered Mental Status (ICD-9-CM code 780.97), Consciousness Alteration (ICD-9-CM code 780.09), or Coma (ICD-9-CM code 780.01). The demographic characteristics, comprehensive records of history of presenting illness, past medical history, home medications, family history, social history, vital signs obtained in the emergency department on admission, detailed physical examination, all laboratory data and investigations obtained during hospitalization, concomitant co-morbidities, and the course of treatment and

management in the hospital were all examined (Table 1). After review of the records by two of the authors, we re-classified 2 patients admitted with the diagnosis of myxedema coma as not 
having that disease and two control patients as having myxedema coma. The re-classification was based on the clinical expertise of the authors.

A screening tool for myxedema coma was developed from a set of 6 inclusion criteria honed from characteristics found in our patient population and patients from the literature (Table 2). The criteria were selected in an attempt to minimize the number of criteria needed to make the diagnosis of myxedema coma by only including those that are most relevant. This is in keeping with our goal of creating an accurate tool that is also expedient. A search of myxedema coma in the medical literature, primarily Medline $^{\circledR}$, resulted in the identification of 365 manuscripts. Of those, 3 studies were selected because the authors had published patient descriptions with enough information to be useful in our screening tool: Dutta et al (9), Rodriguez et al (6), and Yamamoto et al (10). Other definitions of myxedema coma from case review articles and several case reports were also taken into consideration.

After developing the six criteria, a score was assigned to each criterion based on the observation of our patients and the emphasis of each criterion in the literature, with the most weight being given to altered mental status and increased TSH. The intent was to develop 3 categories of patients based on the criteria that would predict the likelihood of myxedema coma.

To test our screening tool, we evaluated data on a different set of patients with known thyroid disease, as indicated by elevated TSH levels and an admitting diagnosis of altered mental status, but who had not been diagnosed with myxedema coma. These patients were admitted during the same time period as our study group (Table 3).

Ten patients with a diagnosis of myxedema coma were used as our study subjects to develop the criteria for the screening tool. The 6 criteria used were the Glasgow Coma Scale (11) (Table 8) measured on admission, thyroid stimulating hormone (TSH $\geq 15 \mathrm{mU} / \mathrm{L}$ ), free $\mathrm{T} 4$ (FT4, 
$<0.6 \mathrm{ng} / \mathrm{dL}$ ), hypothermia (temperature less than $95^{\circ} \mathrm{F}$ ), bradycardia (heart rate less than 60 beats per minute), and the presence of a precipitating factor (Table 2).

The scores assigned to each criterion are listed in Table 4. Patients were divided into 3 groups based on the total scores. If the total score was $>7$, we suggested that they had myxedema coma; if the score was $5-7$, we suggested that myxedema coma was likely if no other plausible cause was present; and if the score was $<5$, we suggested that the patient was unlikely to have myxedema coma and another diagnosis should be considered (Table 4).

The data collected on 13 patients who served as the control group were used in our statistical analysis (Table 3).

\section{STATISTICAL ANALYSIS}

Data analysis was performed using R (12) and the ROCR package (13). The ROC (Receiver Operating Characteristic) Curve was used to determine the sensitivity and specificity of our screening tool (Figure 1). The ROC analysis performed using all 10 patients with a diagnosis of myxedema coma and the 13 patients in the control group. A logistic regression model using the 23 patients and the variables of heart rate, temperature, Glasgow Coma Score (GCS), TSH, FT4, and the presence or absence of illness (such as a precipitating event) or disease was performed to validate the relationship between these variables and the diagnosis of myxedema coma. 


\section{RESULTS}

The median age of the study population was 82 years and all were female. They all had a GCS of less than 15. Four patients were hypothermic. Six patients were found to be bradycardic. Seven patients had a TSH $>30 \mathrm{mU} / \mathrm{L}$. The free thyroxine level was not measured in all patients. Five patients had an identifiable precipitating factor. (Table 1)

The control group of 13 patients (Table 3) admitted with altered mental status and elevated TSH had a median age of 70 years. Only seven patients scored a GCS of less than 15 (including patient 5) despite documented confusion. Confusion itself warrants a score of four out of five in the verbal response category of the GCS so that all patients should have had a GCS score of no greater than 14 . We did not, however, alter the documented GCS scores reported by the ER nurses on admission because the ER reported GCS would be used to make the original diagnosis. Thus in reality, these 13 patients should have had a GCS score of less than 15 . All patients had an elevated TSH. Three of the thirteen patients had a TSH $>30 \mathrm{mU} / \mathrm{L}$. None of the patients had documented hypothermia. Only one patient was bradycardic. Nine patients had an identifiable precipitating factor. The free thyroxine level was obtained in three patients and all three were within the normal range of $0.6-1.5 \mathrm{ng} / \mathrm{dL}$.

Using both literature recommendations and examination of our myxedema coma study population, we selected the following variables to predict the presence of myxedema coma: GCS, TSH, temperature, pulse, and the presence or absence of another illness. While additional variables could have been added, we wished to minimize the variables required for the scoring tool. With these variables, we ran a logistic regression model using all 23 patients (10 subjects and 13 controls). None of these variables alone significantly contributed to the model. However, 
the overall model itself was highly significant with $(P=0.012)$. This provides strong support for using these variables in our myxedema coma tool scoring system.

Based on our scoring system, of the ten study patients diagnosed with myxedema coma, one patient had definite myxedema coma, seven were in the "Likely" category and two were unlikely to have myxedema coma. One of the two patients unlikely to have myxedema coma had secondary hypothyroidism. The other patient that was in the unlikely category did not have FT4 measured or a precipitating factor identified (Table 6).

Based on our scoring system applied to the control group, two patients were classified into the "Likely" Category, while eleven were in the "Unlikely" category. The two patients who fell into the likely category had a more plausible diagnosis than myxedema coma. (Table 6)

The ROC (Receiver Operating Characteristic) Curve was used to determine a cut off score to maximize true positive and minimize false positive. We performed the ROC analysis on the 23 subjects and controls. The optimal value occurs where the curve is nearest the upper left corner (Figure 1A). This point corresponds to a score value of 5 and is associated with a sensitivity of about $80 \%$ and a specificity of about $80 \%(1-$ specificity $=20 \%)$. An area under the curve (AUC) of greater than 0.8 suggests the test performs with high accuracy (14), and the AUC for the graph is 0.865 .

The value of the scoring system was further supported by using the scoring system alone in a regression model to predict myxedema coma. That was also statistically significant with $(P=$ 0.019). Thus, the scoring system works nearly as well as modeling with all variables.

We used 2 additional techniques to validate our system. First, we used bootstrapping (sampling with replacement) to create an array of 500 samples from the 23 subjects and controls. Without having an additional source of subjects to sample, bootstrapping allows us to be sure 
that a few outliers in our 23 patients did not account for the significant relationship between the chosen variables and the outcome. With this array, we ran a separate ROC analysis with similar results: The sensitivity and specificity were 0.64 and 1.0, respectively, at a cutoff of 7 for the disease. The AUC was 0.87 (data not shown).

The second technique we used was to apply our model to the 25 patients reported in the literature to have myxedema coma for whom there was sufficient data to abstract. This showed that our model successfully labeled 24 of the 25 into the "Most Likely" category (Table 5). Further, when we included these 25 reported cases with our own 23 subjects and controls, and repeated the ROC analysis, we found the model gave a sensitivity of 0.8 and specificity of 1.0 at a cutoff of 6 (Fig. 1B). 


\section{DISCUSSION}

Myxedema is a term suggested by Ord in 1878 to describe a condition with a myriad of symptoms related to "mucous oedema" that resulted in vascular and nervous disorders (15). Summers, 75 years after Ord, focused on coma as a terminal event of myxedema in 4 patients, all of whom had extremely low body temperature (16). Most articles in the literature agree that myxedema coma is a form of hypothyroidism with physiological decompensation, suggested clinically by the presence of altered mental status, hypothermia, and the identification of a precipitating factor such as cold exposure, sepsis or drugs $(1,2,6,17)$. However, myxedema coma has not been consistently defined using all the same parameters. Indeed, the mechanisms leading to this clinical condition may be different in different individuals. This may reflect the tendency of the disease to be a combination of many processes within an individual. This combination adds to the complexity of a) making the diagnosis, b) optimizing treatment, and c) understanding the increased mortality of the disease.

Before studying the most effective treatment for myxedema coma, a suitable definition of this condition needs to be established. Our study was the first to develop and test an objective tool for determining whether or not a patient does indeed have myxedema coma. One aspect of the tool that we considered necessary was the ability to make an early assessment with a high degree of specificity and sensitivity that could also be done rapidly and with the least amount of effort. The need for accurate expediency led us to restrict our criteria to the 6 characteristics that are most likely affected in this disease.

Among our selected criteria is the TSH level of the patient. Although elevated TSH levels are common in patients with myxedema coma, it is not a sine qua non. For example, patients 
with pituitary disease would not have elevated TSH levels but may have myxedema coma as has been reported (9). Thus, we have included TSH levels in our screening tool.

Altered mental status may be manifested as cognitive deterioration, lethargy, confusion, or disorientation $(1,18-20)$. In our study, all our patients (subjects and controls) were documented to have altered mental status. However, the ER nurse inaccurately assigned a GCS score of 15 to patients who displayed disorientation or confusion. Because this was a retrospective analysis and we did not personally examine each patient, we elected to not alter the GCS that had been assigned. Nevertheless, when we re-analyzed with an altered the GCS, it did not make a significant difference in the outcome.

According to several authors, hypothermia can be found in virtually all patients; however, the body temperature may be normal due to concurrent infection $(1,2)$. Only $40 \%$ of our patients had hypothermia. In a study reported by Dutta et al., 15 of 23 patients presented in winter, and cold exposure was considered to be a major precipitating factor (9). In 1960, J.H Angel suggested that hypothermia itself maybe an indication for immediate treatment with a rapidly acting thyroid hormone (21).

The possibility of a precipitating infection or other acute illness should always be considered. Fifty percent of our studied population had an identifiable precipitating factor. Indeed, infection was the most common of those factors. A precipitating factor was evident in only 34 of 77 cases in an analysis of myxedema coma reported by Forester (7). Sepsis was the most common precipitating factor among the 23 patients with myxedema coma in a study reported by Dutta et al (9).

Interestingly, two patients in our study who were diagnosed with myxedema coma had subclinical hypothyroidism. A similar observation was recorded in a case report by Mallipedhi et 
al (5). Thus, myxedema coma with subclinical hypothyroidism may not be extremely rare. Of our 10 patients, eight were treated with IV levothyroxine, and two were treated with oral levothyroxine. One of the two patients treated with oral levothyroxine had resolution of her mental status on the day of admission. Therefore, we reported this as a false positive in our study as this patient was likely misdiagnosed with myxedema coma. In addition to this false positive, we found our screening tool provided a false negative on a patient with central hypothyroidism due to an unusually low TSH.

We acknowledge that there are limitations in this study. As with any chart review, information is a direct extraction from patients' charts; thus errors and biases may occur. One such bias was the documentation of the GCS score. Other biases include the many instances in which the precipitating factors were not identified. This, in part, may be because we are uncertain of the types or sorts of precipitating factors. For example, is stroke a precipitating factor or the real cause of altered mental status in a patient with profoundly elevated TSH and low FT4? As for the laboratory data, there were many cases in which the FT4 was not obtained. Certainly if the patient were to have secondary hypothyroidism the absence of a FT4 and the presence of a "normal” TSH can contribute to a lower sensitivity of our tool.

Another limitation is the cutoff of 5 for the diagnosis of myxedema coma (Table 2). While this value is consistent with the ROC analysis performed on our own 23 subjects, when the additional 25 patients from the literature were added to our own 23 to perform a ROC analysis, the cutoff was determined to be 6. Clearly an analysis with further cases and controls will provide greater confidence in the designated cutoff value for identifying myxedema coma.

As we begin to understand further the mechanisms that lead to the clinical manifestations of thyroid dysfunction, it is clear that a measured TSH or a measured free T4 is inadequate to 
fully explain the clinical presentation. The complexity of thyroid hormone action at the tissue level is influenced by multiple factors at both the genomic and post-genomic level. Consequently, there is a spectrum of manifestations of the hypothyroid state. We believe that analogous to the widely appreciated Burch and Wartofsky scoring system for thyroid storm (22), a scoring system for myxedema coma will help to appropriately diagnose this condition, which is a manifestation in part of the degree of hypothyroidism and the influence of multiple other factors.

Our purpose was to create a simple usable tool that would easily allow ER physicians and hospitalists to screen for myxedema coma. Since the time our preliminary findings and initial myxedema coma screening tool were introduced in 2011 (8), we have become aware of a recently published manuscript with a scoring system for myxedema coma that is similar but more comprehensive than our own (23). The more involved system includes gastrointestinal findings, a list of cardiovascular problems (in addition to bradycardia), and several conditions of metabolic disturbance. While a more complicated tool may provide better sensitivity and specificity, we believe that the simpler the tool the more likely it will be used. We present our original research to allow continued discussion for the creation of a refined diagnostic tool that will then permit a future prospective multicenter study to be conducted to determine the optimal treatment for myxedema coma. 


\section{ACKNOWLEDGMENTS}

The authors have nothing to disclose. All authors have read the journal's authorship agreement and policy on disclosure of potential conflicts of interest. All authors have read the journal's authorship agreement and the manuscript has been reviewed by and approved by all named authors. 


\section{REFERENCES}

1. $\quad$ Fliers, E., and Wiersinga, W.M. 2003. Myxedema coma. Rev Endocr Metab Disord 4:137-141.

2. Wartofsky, L. 2006. Myxedema coma. Endocrinol Metab Clin North Am 35:687-698, vii-viii.

3. Werner, S.C., Ingbar, S.H., Braverman, L.E., and Utiger, R.D. 2000. Werner \& Ingar's The thyroid: a fundamental and clinical text. Philadelphia: Lipincott Williams \& Wilkins.

4. Gupta, K.J. 2013. Myxedema coma: a sleeping giant in clinical practice. Am J Med 126:e3-4.

5. Mallipedhi, A., Vali, H., and Okosieme, O. 2011. Myxedema coma in a patient with subclinical hypothyroidism. Thyroid 21:87-89.

6. Rodriguez, I., Fluiters, E., Perez-Mendez, L.F., Luna, R., Paramo, C., and Garcia-Mayor, R.V. 2004. Factors associated with mortality of patients with myxoedema coma: prospective study in 11 cases treated in a single institution. $J$ Endocrinol 180:347-350.

7. Forester, C.F. 1963. Coma in myxedema. Report of a case and review of the world literature. Arch Intern Med 111:734-743.

8. Chiong, Y., and Mariash, C. 2011 Development of an objective tool for the diagnosis of myxedema coma. In ENDO 2011: The Endocrine Society 93rd Annual Meeting. Boston, Massachusetts.

9. Dutta, P., Bhansali, A., Masoodi, S.R., Bhadada, S., Sharma, N., and Rajput, R. 2008. Predictors of outcome in myxoedema coma: a study from a tertiary care centre. Crit Care 12:R1.

10. Yamamoto, T., Fukuyama, J., and Fujiyoshi, A. 1999. Factors associated with mortality of myxedema coma: report of eight cases and literature survey. Thyroid 9:1167-1174.

11. Jennett, B., and Teasdale, G. 1977. Aspects of coma after severe head injury. Lancet 1:878-881.

12. R Core Team. 2012. $R$ : A language and environment for statistical computing. $R$ Foundation for Statistical Computing. Vienna, Austria. ISBN 3-900051-07-0, URL http://www.R-project.org/.

13. Sing, T., Sander, O., Beerenwinkel, N., and Lengauer, T. 2009. Visualizing the performance of scoring classifiers. $R$ package version 1.0-4. http://CRAN.R-project.org/package=ROCR. 
14. Zweig, M.H., and Campbell, G. 1993. Receiver-operating characteristic (ROC) plots: a fundamental evaluation tool in clinical medicine. Clin Chem 39:561-577.

15. Ord, W.M. 1878. On Myxoedema, a term proposed to be applied to an essential condition in the "Cretinoid" Affection occasionally observed in Middle-aged Women. Medico-chirurgical transactions 61:57-78 55.

16. Summers, V.K. 1953. Myxoedema coma. Br Med J 2:366-368.

17. Nicoloff, J.T., and LoPresti, J.S. 1993. Myxedema coma. A form of decompensated hypothyroidism. Endocrinol Metab Clin North Am 22:279-290.

18. Kwaku, M.P., and Burman, K.D. 2007. Myxedema coma. J Intensive Care Med 22:224-231.

19. Reinhardt, W., and Mann, K. 1997. [Incidence, clinical picture and treatment of hypothyroid coma. Results of a survey]. Med Klin (Munich) 92:521-524.

20. Tsitouras, P.D. 1995. Myxedema coma. Clin Geriatr Med 11:251-258.

21. Angel, J.H., and Sash, L. 1960. Hypothermic coma in myxoedema. Br Med J 1:1855-1859.

22. Burch, H.B., and Wartofsky, L. 1993. Life-threatening thyrotoxicosis. Thyroid storm. Endocrinol Metab Clin North Am 22:263-277.

23. Popoveniuc, G., Chandra, T., Sud, A., et al. 2014. A Diagnostic Scoring System for Myxedema Coma. Endocr Pract:1-36.

\section{FIGURE LEGENDS}

Figure 1: Receiver Operating Characteristic (ROC) Curve. ROC analysis of A) all 23 patients (subjects and controls) and B) all patients plus an additional 25 patients reported in the literature to have myxedema coma. AUC is the area under the curve. Arrows indicate the optimal value of sensitivity and specificity. 


\section{Table 1: Clinical and laboratory findings in 10 patients with myxedema coma}

\begin{tabular}{|c|c|c|c|c|c|c|c|c|c|c|}
\hline Patient & Age & Sex & $\begin{array}{l}\text { Precipitating } \\
\text { factors }\end{array}$ & GCS & $\begin{array}{l}\begin{array}{l}\text { Associated } \\
\text { comorbidities }\end{array} \\
\end{array}$ & $\begin{array}{l}\begin{array}{l}\text { TSH } \\
(\mathrm{mU} / \mathrm{L})\end{array} \\
\end{array}$ & $\begin{array}{l}\begin{array}{l}\text { FT4 } \\
\text { (ng/dL) }\end{array} \\
\end{array}$ & $\begin{array}{l}\text { Temp } \\
\left({ }^{\circ} \mathbf{F}\right)\end{array}$ & $\begin{array}{l}\text { HR } \\
\text { (bpm) }\end{array}$ & Outcome \\
\hline 1 & $50 / F$ & $\mathrm{~F}$ & - & 14 & $\begin{array}{l}\text { Hypertension, } \\
\text { Type } 2 \text { Diabetes, } \\
\text { Obstructive Sleep } \\
\text { Apnea }\end{array}$ & 59.7 & 0.3 & 96.8 & 78 & Alive \\
\hline 2 & 93 & $\mathrm{~F}$ & $\begin{array}{l}\text { Urinary Tract } \\
\text { Infection }\end{array}$ & 14 & $\begin{array}{l}\text { Alzheimer's Dementia, } \\
\text { Acute renal failure, } \\
\text { Leukopenia, } \\
\text { Thrombocytopenia }\end{array}$ & 102.8 & - & 91.7 & 52 & Died \\
\hline 3 & 89 & $\mathrm{~F}$ & - & 14 & $\begin{array}{l}\text { Hypertension, } \\
\text { Chronic Obstructive } \\
\text { Pulmonary Disease, } \\
\text { Acute on chronic renal } \\
\text { failure }\end{array}$ & 140 & - & 98.2 & 92 & Alive \\
\hline 4 & 86 & $\mathrm{~F}$ & - & 14 & $\begin{array}{l}\text { Congestive Heart } \\
\text { Failure, } \\
\text { Acute on chronic renal } \\
\text { failure, } \\
\text { Hypoglycemia, } \\
\text { Hyponatremia }\end{array}$ & 95.4 & - & 97.4 & 43 & Alive \\
\hline 5 & 66 & $\mathrm{~F}$ & - & 14 & $\begin{array}{l}\text { Carvenous sinus } \\
\text { meningioma, } \\
\text { Panhypopituitaridism, } \\
\text { Hyponatremia }\end{array}$ & 0.187 & 0.7 & 96.9 & 95 & Alive \\
\hline 6 & 86 & $\mathrm{~F}$ & $\begin{array}{l}\text { Urinary Tract } \\
\text { Infection }\end{array}$ & 14 & $\begin{array}{l}\text { Pancytopenia, } \\
\text { Chronic kidney disease, } \\
\text { Hypertension, } \\
\text { Type } 2 \text { Diabetes, } \\
\text { Alzheimer's dementia }\end{array}$ & 9.48 & 1.2 & 90.4 & 45 & Alive \\
\hline 7 & 83 & $\mathrm{~F}$ & $\begin{array}{l}\text { Aspiration } \\
\text { Pneumonia }\end{array}$ & 10 & $\begin{array}{l}\text { Dementia, } \\
\text { Hypertension, } \\
\text { Dysphagia }\end{array}$ & 11.6 & - & 88.6 & 44 & Alive \\
\hline 8 & 82 & $\mathrm{~F}$ & $\begin{array}{l}\text { Urinary Tract } \\
\text { Infection }\end{array}$ & 13 & $\begin{array}{l}\text { Adrenal insufficiency, } \\
\text { Acute respiratory } \\
\text { failure, } \\
\text { Dysphagia }\end{array}$ & 36.2 & 0.8 & 89.6 & 74 & Alive \\
\hline 9 & 68 & $\mathrm{~F}$ & $\begin{array}{l}\text { Primary } \\
\text { biliary } \\
\text { cirrhosis }\end{array}$ & 8 & $\begin{array}{l}\text { Primary Biliary } \\
\text { Cirrhosis, } \\
\text { Septic shock, } \\
\text { Anemia, } \\
\text { Gastric ulcers }\end{array}$ & 158 & 0.2 & 96.9 & 54 & Alive \\
\hline 10 & 44 & $\mathrm{~F}$ & - & 3 & $\begin{array}{l}\text { Acute respiratory } \\
\text { failure }\end{array}$ & 87.8 & - & 97.5 & 51 & Alive \\
\hline
\end{tabular}

Abbreviations: GCS, Glascow Coma Score; FT4, Free T4; Temp, Temperature; HR, Heart Rate; bpm, beats per minute 
Table 2. Comparing the percentage of patients with the six criteria used in Myxedema

Coma screening tool between the literature and our study.

\begin{tabular}{|c|c|c|c|c|c|}
\hline Criterion & $\begin{array}{c}\text { Dutta (9) } \\
(\mathrm{N}=23)\end{array}$ & $\begin{array}{c}\text { Rodriguez (6) } \\
\quad(\mathrm{N}=11)\end{array}$ & $\begin{array}{c}\text { Yamamoto } \\
\qquad(10) \\
(\mathrm{N}=8)\end{array}$ & $\begin{array}{c}\text { Our Study } \\
(\mathrm{N}=10)\end{array}$ & $\begin{array}{l}\text { Our Control } \\
\qquad(\mathrm{N}=13)\end{array}$ \\
\hline AMS & $100 \%$ & $100 \%$ & $100 \%$ & $100 \%$ & $54 \%$ \\
\hline Hypothermia ${ }^{1}$ & $100 \%$ & $100 \%$ & $75 \%$ & $40 \%$ & $0 \%$ \\
\hline Bradycardia $^{2}$ & - & $54.54 \%$ & $87.5 \%$ & $60 \%$ & $8 \%$ \\
\hline Elevated TSH & $83 \%$ & $81.81 \%$ & $100 \%$ & $90 \%$ & $100 \%$ \\
\hline Low FT4 or TT4 & $100 \%$ & $100 \%$ & $100 \%$ & $20 \%$ & $0 \%$ \\
\hline $\begin{array}{l}\text { Precipitating } \\
\text { Illness }^{3}\end{array}$ & $100 \%$ & $100 \%$ & $100 \%$ & $50 \%$ & $69 \%$ \\
\hline
\end{tabular}

Abbreviations: AMS, altered mental status; TSH, thyroid stimulating hormone; FT4, free thyroxine; TT4, total thyroxine.

${ }^{1}$ Body temperature less than $95^{\circ} \mathrm{F}$ measured on admission.

${ }^{2}$ Heart rate less than 60 beats per minute measured on admission.

${ }^{3}$ Burns, carbon monoxide retention, gastrointestinal hemorrhage, infection, sepsis, medications, stroke, surgery, trauma etc (17) 
Table 3: 13 patients admitted with altered mental status and elevated TSH levels

\begin{tabular}{|c|c|c|c|c|c|c|c|c|c|c|}
\hline Patient & Age & Sex & $\begin{array}{l}\text { Precipitating } \\
\text { factors }\end{array}$ & GCS & $\begin{array}{l}\text { Associated } \\
\text { comorbidities }\end{array}$ & $\begin{array}{l}\text { TSH } \\
(\mathrm{mU} / \mathrm{L})\end{array}$ & $\begin{array}{l}\text { FT4 } \\
\text { (ng/dL) }\end{array}$ & $\begin{array}{l}\text { Temp } \\
\left({ }^{\circ} \mathrm{F}\right)\end{array}$ & $\begin{array}{l}\text { HR } \\
\text { (bpm) }\end{array}$ & Outcome \\
\hline 1 & 62 & $\mathrm{~F}$ & - & 14 & $\begin{array}{l}\text { ESRD, } \\
\text { Congestive Heart } \\
\text { failure }\end{array}$ & 12.5 & - & 100.9 & 99 & Alive \\
\hline 2 & 75 & M & Dehydration & 15 & $\begin{array}{l}\text { Chronic renal } \\
\text { failure, } \\
\text { Hypertension, } \\
\text { Hypernatremia }\end{array}$ & 14.857 & - & 97.9 & 82 & Alive \\
\hline 3 & 70 & $\mathrm{~F}$ & $\begin{array}{l}\text { Urinary Tract } \\
\text { Infection }\end{array}$ & 15 & Dementia & 5.01 & 0.8 & 98.1 & 83 & Alive \\
\hline 4 & 83 & M & $\begin{array}{l}\text { Aspiration } \\
\text { Pneumonia }\end{array}$ & 15 & $\begin{array}{l}\text { Congestive heart } \\
\text { failure, } \\
\text { Orthostatic } \\
\text { hypotension, } \\
\text { DVT, } \\
\text { Acute renal } \\
\text { failure }\end{array}$ & 46.06 & - & 97.7 & 71 & Alive \\
\hline 5 & 64 & F & $\begin{array}{l}\text { Valproic Acid } \\
\text { Toxicity }\end{array}$ & - * & Hypertension & 25.516 & - & 96.7 & 80 & Alive \\
\hline 6 & 67 & $\mathrm{~F}$ & $\begin{array}{l}\text { Urinary Tract } \\
\text { Infection }\end{array}$ & 15 & $\begin{array}{l}\text { Hypertension, } \\
\text { Acute on chronic } \\
\text { renal failure, } \\
\text { Dementia }\end{array}$ & 61.319 & - & 98.9 & 56 & Alive \\
\hline 7 & 51 & M & $\begin{array}{l}\text { Medication } \\
\text { (marijuana, } \\
\text { opiates, } \\
\text { benzodiapezine) }\end{array}$ & 14 & Hypotension & 21.962 & 1.1 & 96.2 & 60 & Alive \\
\hline 8 & 75 & $\mathrm{~F}$ & - & 15 & $\begin{array}{l}\text { Hypertensive } \\
\text { emergency, } \\
\text { ESRD, } \\
\text { Pulmonary } \\
\text { hypertension, } \\
\text { Dementia, } \\
\text { Constipation }\end{array}$ & 4.225 & 0.6 & 98.2 & 68 & Alive \\
\hline 9 & 83 & $\mathrm{~F}$ & $\begin{array}{l}\text { Urinary Tract } \\
\text { Infection, } \\
\text { medications } \\
\text { (Codeine) }\end{array}$ & 15 & Hypertension & 6.825 & - & 97.8 & 91 & Alive \\
\hline 10 & 81 & F & Cellulitis & 13 & $\begin{array}{l}\text { ESRD, } \\
\text { Hypotension, } \\
\text { Chronic subdural } \\
\text { hematoma, } \\
\text { Congestive heart } \\
\text { failure }\end{array}$ & 8.847 & - & 97.7 & 88 & Alive \\
\hline
\end{tabular}




\begin{tabular}{|c|c|c|c|c|c|c|c|c|c|c|}
\hline 11 & 78 & $\mathrm{~F}$ & $\begin{array}{l}\text { Nasal } \\
\text { Hemorrhage }\end{array}$ & 14 & $\begin{array}{l}\text { Hemorrhagic } \\
\text { shock, } \\
\text { Esophageal } \\
\text { cancer, } \\
\text { Acute respiratory } \\
\text { failure, } \\
\text { Cardiac arrest }\end{array}$ & 74.795 & - & 98.3 & 123 & Died \\
\hline 12 & 69 & $\mathrm{~F}$ & Pneumonia & 8 & $\begin{array}{l}\text { Septic shock, } \\
\text { SVT, } \\
\text { Decubitus ulcers, } \\
\text { Acute respiratory } \\
\text { failure, } \\
\text { Atrial fibrillation } \\
\text { with RVR, } \\
\text { Acute renal } \\
\text { failure, } \\
\text { Type } 2 \text { Diabetes }\end{array}$ & 5.271 & - & 101.7 & 195 & Died \\
\hline 13 & 61 & $\mathrm{~F}$ & $\begin{array}{l}\text { Medication } \\
\text { (Benzodiazepine) }\end{array}$ & 14 & $\begin{array}{l}\text { Hypertensive } \\
\text { urgency }\end{array}$ & 8.892 & - & 98.4 & 72 & Alive \\
\hline
\end{tabular}

Abbreviations: ESRD, End stage renal disease; DVT, deep vein thrombosis; SVT, supraventricular tachycardia; RVR, rapid ventricular rate.

* Suspected GCS of 14. 


\section{Table 4: Myxedema Coma Screening Tool}

\begin{tabular}{|c|c|c|}
\hline \multicolumn{2}{|c|}{ Criterion } & Score \\
\hline \multicolumn{2}{|c|}{ GCS } & \\
\hline \multicolumn{2}{|c|}{$0-10$} & 4 \\
\hline \multicolumn{2}{|c|}{$11-13$} & 3 \\
\hline \multicolumn{2}{|c|}{14} & 2 \\
\hline \multicolumn{2}{|c|}{15} & 0 \\
\hline \multicolumn{3}{|c|}{ TSH } \\
\hline \multicolumn{2}{|c|}{ More than $30 \mathrm{mU} / \mathrm{L}$} & 2 \\
\hline \multicolumn{2}{|c|}{ Between 15-30 mU/L } & 1 \\
\hline \multicolumn{2}{|c|}{ Low Free $\mathrm{T} 4^{1}$} & 1 \\
\hline \multicolumn{2}{|c|}{ Hypothermia $^{2}$} & 1 \\
\hline \multicolumn{2}{|c|}{ Bradycardia $^{3}$} & 1 \\
\hline \multicolumn{2}{|c|}{ Precipitating event ${ }^{4}$} & 1 \\
\hline Total Scores & Category & Recommendation \\
\hline $8-10$ & Most Likely & Proceed with treatment \\
\hline $5-7$ & Likely & $\begin{array}{l}\text { Treat if there are no other } \\
\text { plausible causes }\end{array}$ \\
\hline$<5$ & Unlikely & Consider other diagnosis \\
\hline
\end{tabular}

Abbreviations: GCS, Glasgow Coma Scale; TSH, thyroid stimulating hormone.

${ }^{1}$ Free $\mathrm{T} 4<0.6 \mathrm{ng} / \mathrm{dL}$

${ }^{2}$ Body temperature less than $95^{\circ} \mathrm{F}$ measured on admission.

${ }^{3}$ Heart rate $<60$ beats per minute measured on admission.

${ }^{4}$ Burns, carbon monoxide retention, gastrointestinal hemorrhage, infection, sepsis, medications, stroke, surgery, trauma etc (17) 
Table 5: Characteristics of the 13 patients in the control group

\begin{tabular}{cc}
\hline Criterion & Number of Patients \\
\hline GCS $<15$ & 7 \\
Elevated TSH & 13 \\
Low FT4 & $3^{*}$ \\
Hypothermia $^{2}$ & 0 \\
Bradycardia $^{3}$ & 1 \\
Precipitating event $^{4}$ & 9
\end{tabular}

Abbreviations: GCS, Glasgow Coma Scale; TSH, thyroid stimulating hormone; FT4, free thyroxine.

${ }^{1}$ Free $\mathrm{T} 4<0.6 \mathrm{ng} / \mathrm{dL}$

${ }^{2}$ Body temperature less than $95^{\circ} \mathrm{F}$ measured on admission.

${ }^{3}$ Heart rate less than 60 beats per minute measured on admission.

${ }^{4}$ Burns, carbon monoxide retention, gastrointestinal hemorrhage, infection, sepsis, medications, stroke, surgery, trauma etc (17)

*10 patients had no FT4 obtained. 
Table 6: Proposed scoring system applied to our 23 subjects

\begin{tabular}{|c|c|c|c|c|c|c|c|c|c|c|c|c|c|c|}
\hline \multirow{2}{*}{\begin{tabular}{|l|} 
Patient \\
Study 1
\end{tabular}} & \multicolumn{2}{|c|}{$\begin{array}{l}\text { GCS } \\
\text { /score }\end{array}$} & \multicolumn{2}{|c|}{$\begin{array}{c}\text { TSH } \\
\text { (mU/L) } \\
\text { /score }\end{array}$} & \multicolumn{2}{|c|}{$\begin{array}{c}\text { FT4 } \\
\text { (ng/dL) } \\
\text { /score }\end{array}$} & \multicolumn{2}{|c|}{$\begin{array}{l}\text { Body } \\
\text { Temp } \\
\text { /score }\end{array}$} & \multicolumn{2}{|c|}{$\begin{array}{c}\text { Pulse } \\
\text { (bpm)/ } \\
\text { score }\end{array}$} & \multicolumn{2}{|c|}{$\begin{array}{c}\text { Precipitating } \\
\text { event } \\
\text { /score }\end{array}$} & \multirow{2}{*}{$\begin{array}{c}\text { Total } \\
\text { score } \\
5\end{array}$} & \multirow{2}{*}{$\begin{array}{c}\text { Myxedema } \\
\text { coma } \\
\text { category }\end{array}$} \\
\hline & 14 & 2 & 59.7 & 2 & 0.3 & 1 & 96.8 & 0 & 78 & 0 & no & 0 & & \\
\hline & 14 & 2 & 102.7 & 2 & - & - & 91.7 & 1 & 57 & 1 & yes & 1 & 7 & Likely \\
\hline Study 3 & 14 & 2 & 140.2 & 2 & - & - & 98.2 & 0 & 92 & 0 & no & 0 & 4 & Unlikely \\
\hline Study 4 & 14 & 2 & 95.4 & 2 & - & - & 97.4 & 0 & 43 & 1 & no & 0 & 5 & Likely \\
\hline Study 5 & 14 & 2 & 0.19 & 0 & 0.7 & 0 & 96.9 & 0 & 95 & 0 & no & 0 & 2 & Unlikely \\
\hline Study 6 & 14 & 2 & 9.5 & 0 & 1.2 & 0 & 90.4 & 1 & 45 & 1 & yes & 1 & 5 & Likely \\
\hline Study 7 & 10 & 4 & 11.6 & 0 & - & - & 88.6 & 1 & 44 & 1 & yes & 1 & 7 & Likely \\
\hline Study 8 & 13 & 3 & 36.2 & 2 & 0.8 & 0 & 89.6 & 1 & 74 & 0 & yes & 1 & 7 & Likely \\
\hline Study 9 & 8 & 4 & 158.5 & 2 & 0.2 & 1 & 96.9 & 0 & 54 & 1 & yes & 1 & 9 & Most likely \\
\hline Study 10 & 3 & 4 & 87.8 & 2 & - & - & 97.5 & 0 & 51 & 1 & no & 0 & 7 & Likely \\
\hline Control 1 & 14 & 2 & 12.5 & 0 & - & - & 100.9 & 0 & 99 & 0 & no & 0 & 2 & Unlikely \\
\hline Control 2 & 15 & 0 & 14.9 & 0 & - & & 97.7 & 0 & 82 & 0 & no & 0 & 0 & Unlikely \\
\hline Control 3 & 15 & 0 & 5.0 & 0 & 0.8 & 0 & 98.1 & 0 & 83 & 0 & yes & 1 & 1 & Unlikely \\
\hline Control 4 & 15 & 0 & 46.0 & 2 & - & - & 97.7 & 0 & 71 & 0 & yes & 1 & 3 & Unlikely \\
\hline Control 5 & 14 & 2 & 25.5 & 1 & - & - & 96.7 & 0 & 80 & 0 & yes & 1 & 4 & Unlikely \\
\hline Control 6 & 15 & 0 & 61.3 & 2 & - & - & 98.9 & 0 & 56 & 1 & yes & 1 & 4 & Unlikely \\
\hline Control 7 & 14 & 2 & 22.0 & 1 & 1.1 & 0 & 96.2 & 0 & 60 & 0 & no & 0 & 3 & Unlikely \\
\hline Control 8 & 15 & 0 & 4.2 & 0 & 0.6 & 0 & 98.2 & 0 & 68 & 0 & no & 0 & 0 & Unlikely \\
\hline Control 9 & 15 & 0 & 6.8 & 0 & - & - & 97.8 & 0 & 91 & 0 & yes & 1 & 1 & Unlikely \\
\hline Control 10 & 13 & 3 & 8.8 & 0 & - & - & 97.7 & 0 & 88 & 0 & yes & 1 & 4 & Unlikely \\
\hline Control 11 & 14 & 2 & 74.8 & 2 & - & - & 98.3 & 0 & 123 & 0 & yes & 1 & 5 & Likely \\
\hline Control 12 & 8 & 4 & 5.3 & 0 & - & - & 101.7 & 0 & 195 & 0 & yes & 1 & 5 & Likely \\
\hline Control 13 & 14 & 2 & 8.9 & 0 & - & - & 98.4 & 0 & 72 & 0 & yes & 1 & 3 & Unlikely \\
\hline
\end{tabular}


Table 7: Scoring system applied to 25 patients from the literature diagnosed with myxedema coma

\begin{tabular}{|c|c|c|c|c|c|c|c|c|c|c|c|c|c|c|}
\hline Patient & $\begin{array}{l}\text { GCS } \\
\text { /score }\end{array}$ & & $\begin{array}{r}\text { TSI } \\
(\mathbf{m U} / \\
/ \mathrm{sco}\end{array}$ & & $\begin{array}{c}\text { FT4 } \\
\text { (ng/dL) } \\
\text { /score }\end{array}$ & & $\begin{array}{r}\text { Tem } \\
\left({ }^{\circ} \mathbf{F}\right) \\
\text { scor }\end{array}$ & & $\begin{array}{c}\text { Pulse } \\
\text { (bpm)/ } \\
\text { score }\end{array}$ & & $\begin{array}{r}\text { Precipit } \\
\text { eveI } \\
\text { /sco }\end{array}$ & $\begin{array}{l}\text { tating } \\
\text { nt } \\
\text { re }\end{array}$ & $\begin{array}{l}\text { Total } \\
\text { score }\end{array}$ & $\begin{array}{c}\text { Myxedema } \\
\text { coma } \\
\text { category }\end{array}$ \\
\hline $1(10)$ & Coma & 4 & 227 & 2 & - & - & $<95$ & 1 & $<60$ & 1 & yes & 1 & 9 & Most Likely \\
\hline $2(10)$ & Semicoma & 2 & 52 & 2 & - & - & $<95$ & 1 & $<60$ & 1 & yes & 1 & 7 & Likely \\
\hline $3(10)$ & Coma & 4 & 52 & 2 & - & - & $>95$ & 0 & $<60$ & 1 & yes & 1 & 8 & Most Likely \\
\hline $4(10)$ & Coma & 4 & 28 & 1 & - & - & $<95$ & 1 & $<60$ & 1 & yes & 1 & 8 & Most Likely \\
\hline $5(10)$ & Semicoma & 2 & 62 & 2 & - & - & $<95$ & 1 & $<60$ & 1 & no & 0 & 6 & Likely \\
\hline $6(10)$ & Coma & 4 & 25 & 1 & $<0.2$ & 1 & $>95$ & 0 & $<60$ & 1 & yes & 1 & 8 & Most Likely \\
\hline 7 (10) & Somnolence & 0 & 114 & 2 & $<0.2$ & 1 & $<95$ & 1 & $>60$ & 0 & no & 0 & 4 & Unlikely \\
\hline $8(10)$ & Somnolence & 0 & 127 & 2 & $<0.2$ & 1 & $<95$ & 1 & $<60$ & 1 & yes & 1 & 6 & Likely \\
\hline 9 (5) & Coma & 4 & 6.09 & 0 & 10.7 & 0 & 91.8 & 1 & 88 & 0 & yes & 1 & 6 & Likely \\
\hline $10(24)$ & $\begin{array}{l}\text { Drowsy, } \\
\text { unintelligent } \\
\text { speech }\end{array}$ & 2 & 72 & 2 & - & - & 82.8 & 1 & 40 & 1 & yes & 1 & 7 & Likely \\
\hline 11 (25) & 9 & 4 & 63 & 2 & $\begin{array}{l}\text { Undetect } \\
\text {-able }\end{array}$ & 1 & 87.3 & 1 & 37 & 1 & yes & 1 & 10 & Most Likely \\
\hline $12(26)$ & $\begin{array}{l}\text { Lethargic - } \\
\text { >apniec }\end{array}$ & 4 & - & - & - & - & 96.8 & 0 & $<60-62$ & 1 & yes & 1 & 6 & Likely \\
\hline 13 (27) & 8 & 4 & $>50$ & 2 & - & - & 95.4 & 0 & 54 & 1 & yes & 1 & 8 & Most Likely \\
\hline $14(28)$ & $\begin{array}{l}\text { Drowsy>LIC/ } \\
\text { intubated }\end{array}$ & 4 & $>200$ & 2 & $<0.3$ & 1 & 86.2 & 1 & 60 & 0 & yes & 1 & 9 & Most Likely \\
\hline 15 (6) & Obtunded & 2 & 51.3 & 2 & 0.46 & 1 & 94.1 & 1 & 39 & 1 & yes & 1 & 8 & Most Likely \\
\hline $16(6)$ & Coma & 4 & 0.43 & 0 & 0.25 & 1 & 93.9 & 1 & 124 & 0 & yes & 1 & 7 & Likely \\
\hline 17 (6) & Coma & 4 & 71 & 2 & 0.18 & 1 & 93.0 & 1 & 38 & 1 & yes & 1 & 10 & Most Likely \\
\hline $18(6)$ & Obtunded & 2 & 2.54 & 0 & 0.23 & 1 & 94.8 & 1 & 104 & 0 & yes & 1 & 5 & Likely \\
\hline 19 (6) & Obtunded & 2 & 76.0 & 2 & 0.28 & 1 & 93.6 & 1 & 114 & 0 & yes & 1 & 7 & Likely \\
\hline $20(6)$ & Coma & 4 & 28 & 1 & 0.17 & 1 & 94.6 & 1 & 38 & 1 & no & 0 & 8 & Most Likely \\
\hline $21(6)$ & Obtunded & 2 & 38 & 2 & 0.15 & 1 & 95 & 0 & 124 & 0 & yes & 1 & 6 & Likely \\
\hline $22(6)$ & Coma & 4 & 60.6 & 2 & 0.15 & 1 & 95 & 0 & 65 & 0 & yes & 1 & 8 & Most Likely \\
\hline $23(6)$ & Obtunded & 2 & 153 & 2 & 0.15 & 1 & 94.6 & 1 & 52 & 1 & yes & 1 & 8 & Most Likely \\
\hline 24 (6) & Obtunded & 2 & 9.85 & 0 & 0.37 & 1 & 94.8 & 1 & 144 & 0 & yes & 1 & 5 & Likely \\
\hline 25 (6) & Obtunded & 2 & 78.2 & 2 & 0.5 & 1 & 92.5 & 1 & 38 & 1 & yes & 1 & 8 & Most Likely \\
\hline
\end{tabular}


Abbreviations and format are the same as in Table 6. 
Table 8. Glasgow Coma Scale

\begin{tabular}{llc} 
Activity & Best response & Score \\
\hline Eye Opening & Spontaneous & 4 \\
& To speech & 3 \\
& To pain & 2 \\
Verbal response & None & 1 \\
& Oriented & 5 \\
& Confused & 4 \\
& Inappropriate words & 3 \\
& Incomprehensible sounds & 2 \\
& None & 1 \\
Motor response & Obeys & 6 \\
& Localizes pain & 5 \\
& Withdraws from pain & 4 \\
& Abnormal flexion & 3 \\
& Extension & 2 \\
\hline
\end{tabular}

\footnotetext{
${ }^{a}$ Glasgow Coma Scale used to define coma: Responses to stimuli are scored based on the patient's ability to open eyes and obey verbal and motor commands. The responsive score ranges from 3 to 15 . A sum $\leq 7$ indicates a comatose state. (9)
} 